\title{
PENGARUH SIKAP BERBAHASA TERHADAP PENERAPAN BAHASA INDONESIA DALAM PENULISAN SKRIPSI MAHASISWA FAKULTAS ILMU BUDAYA, UNIVERSITAS DIPONEGORO
}

\author{
Rati Riana dan Sofyandanu Setiadi \\ Dosen Bahasa Indonesia Universitas Semarang
}

\begin{abstract}
Abstrak
Penelitian ini bertujuan untuk (a) mendeskripsi apakah sikap berbahasa berpengaruh terhadap penerapan bahasa Indonesia pada skripsi mahasiswa Fakultas Ilmu Budaya, Universitas Diponegoro dan (b) mendeskripsi bentuk pengaruh sikap berbahasa Indonesia terhadap penerapan berbahasa pada skripsi mahasiswa Fakultas Ilmu Budaya, Universitas Diponegoro. Penelitian ini dilakukan di Fakultas Ilmu Budaya, Universitas Diponegoro dengan mengambil objek mahasiswa sebanyak 80 orang. Faktor pengaruh yang dianalisis adalah sikap berbahasa. Data dianalisis dengan analisis deskriptif dengan menggunakan statistik deskriptif (skor terendah, skor tertinggi, skor rata-rata, dan standar deviasi). Kriteria sikap berbahasa yang dikategorikan positif dan negatif diambil dari nilai rata-rata nilai idealnya. Dari 1425 buah kalimat, ditemukan $1.002(70,312 \%)$ buah kalimat gramatikal yang penerapannya sesuai dengan kaidah berbahasa Indonesia dan 286 (20,09\%) buah kalimat yang penerapannya tidak sesuai dengan kaidah. Ketidaksesuain penerapan berbahasa tersebut disebabkan kalimat tidak gramatikalan. Ketidakgramatikalan kalimat tersebut disebabkan oleh kalimat tanpa subjek, tanpa predikat, dengan 2 subjek, 2 predikat, dan kalimat dengan 2 subjek dan 2 predikat, serta kalimat tanpa subjek dan tanpa predikat. Selain itu, ditemukan pula kesalahan dalam pemilihan kata/diksi dan kesalahan penerapan ejaan sejumlah $137(9,61 \%)$ buah kalimat. Hasil ini ini merupakan pengaruh sikap berbahasa mahasiswa yang kurang menaati kaidah berbahasa Indonesia dalam penulisan karya ilmiah.

Kata Kunci : sikap berbahasa, penulisan skripsi.
\end{abstract}

\begin{abstract}
This research aims to (A) describing if the application of the effect on language attitudes language Indonesia really has impact towards cultural studies student thesis in the University of Diponegoro, and (b) describing the shape of Indonesia-speaking attitude towards student thesis on language application in the University of Diponegoro. This research was conducted at the Faculty of cultural studies, University of Diponegoro by taking student as its 80 object. The influence factors analysis is a language attitude. Data were analyzed with descriptive analysis using descriptive statistics The lowest score, highest score, average score and the ideal attitude of total language every answer question item. Language attitudes are categorized criteria positive and negative is taken from the value of the average values of ideally. Results of the research findings of the eight circles are found as much as 1425 fruit sentence. From 1425 fruit sentence, found 1,002 (70,312) grammatical sentences the fruit its application in accordance with the rules of speaking in Indonesia and $286(20,09)$ fruit of the sentence that the application does not comply with the rule. Ketidaksesuain application of the language due to the sentence is not gramatikalan. Ketidakgramatikalan the sentence due to a sentence without a subject, without a predicate, with 2 subjects, predicates, and 2 sentences to two subjects and predicates, as well as 2 sentences without subject and without a predicate. In addition, the found errors in word choice/diction and spelling a number of application error 137 (9,61) fruit of the sentence. This result is the influence the attitude of the students speak less obey the rules of speaking in Indonesia in the writing of scientific papers.
\end{abstract}

Keywords: language-attitude, thesis-writings 


\section{PENDAHULUAN}

\section{Latar Belakang Masalah}

Karangan ilmiah merupakan hasil penuangan ide penulis. Dalam penyusunannya, dipengaruhi oleh beberapa faktor, di antaranya perkuliahan, sikap berbahasa, dan pembimbingan. Faktor perkuliahan, antara lain pemberian materi kuliah bahasa Indonesia, sangat berperan untuk menghasilkan kualitas bahasa karya ilmiah. Pemberian materi bahasa Indonesia dalam perkuliahan diharapkan dapat mewujudkan kualitas bahasa karya ilmiah mahasiswa. Akan tetapi, pada kenyataannya harapan tersebut belum sepenuhnya terwujud. Penerapan bahasa baku yang mencakupi ejaan, ketepatan pilihan kata, keefektifan kalimat, kadang tidak terpenuhi. Hal ini diduga karena sikap mahasiswa yang menganggap bahwa mata kuliah Bahasa Indonesia kurang penting apabila dibandingkan dengan mata kuliah lain atau juga kekurangpedulian mahasiswa dalam memahami bahasa Indonesia secara benar.

Pemahaman bahasa Indonesia sesuai dengan kaidah berbahasa Indonesia yang baik dan benar diperlukan bagi mahasiwa dengan tujuan agar mahasiswa mempunyai sikap yang positif terhadap bahasa Indonesia. Sikap berbahasa yang positif ini, antara lain dengan menunjukkan kesetiaan berbahasa, kebanggaan berbahasa, dan kesadaran akan adanya norma bahasa. Sikap bahasa yang positif terhadap bahasa Indonesia diharapkan agar mahasiswa dapat menghasilkan karangan ilmiah yang berkualitas.

Akan tetapi, sikap berbahasa yang positif ini belum sepenuhnya dimiliki oleh mahasiswa. Kesadaran rasa setia, bangga memiliki, dan memelihara bahasa Indonesia masih kurang. Indikasi ini bisa diketahui karena mahasiswa sering memilih bahasa asing dalam pengungkapan maksudnya walaupun dalam bahasa Indonesia sudah ada padanan katanya. Juga kesadaran dalam norma berbahasa masih rendah. Temuantemuan seperti itu diungkapkan oleh Moeliono (1991:34) bahwa kebanyakan kaum terpelajar sekarang menganggap bahasa Indonesia tidak merupakan bahasa pertama yang dipelajari, bahasa nasional kita banyak mengalami serapan bahasa lain. Akibatnya ialah kenyataan pahit, yakni kurangnya kesetiaan akan berbahasa Indonesia, tiadanya kebanggaan agar fasih berbahasa Indonesia, dan tidak adanya kesadaran akan adanya suatu tolok atau patokan.

Menurut Gerungan (2004:161) bahwa istilah sikap dapat diterjemahkan sebagai pandangan atau perasaan yang disertai oleh kecenderungan untuk bertindak terhadap suatu objek tertentu. Walgito (2003:110) mengatakan bahwa sikap merupakan organisasi dari pendapat, keyakinan seseorang mengenai suatu objek atau situasi yang sama, disertai oleh suatu perasaan tertentu dan memberikan dasar kepada individu tersebut untuk membuat respon atau berperilaku dalam cara yang tertentu yang dipilihnya. Sikap adalah sekelompok keyakinan dan perasaan yang melekat tentang objek tertentu dan kecenderungan untuk bertindak terhadap objek tersebut dengan cara tertentu (Calhoun \& Acocella, 1995:115). Sikap adalah reaksi atau respon yang masih tertutup dari seseorang terhadap suatu stimulus atau obyek (Notoatmodjo, 2005:124). Ajzen (2005:5) mengatakan bahwa sikap sebagai predisposisi yang dipelajari individu untuk memberikan respon suka atau tidak suka secara konsisten terhadap objek sikap. Respon suka atau tidak suka itu adalah hasil 
proses evaluasi terhadap keyakinankeyakinan (beliefs) individu terhadap objek sikap (Fishbein \& Ajzen, 1975: 6). Baron dan Byrne (2004 : 120) bahwa sikap merujuk pada evaluasi yang dilakukan terhadap aspek dunia sosial serta bagaimana evaluasi tersebut memunculkan rasa suka dan tidak suka terhadap isu, ide, orang, kelompok sosial, atau objek. Sikap sebagai respon evaluatif menunjukkan ekspresi suka atau tidak suka, setuju atau tidak setuju, mendekati atau menghindari, dan tertarik atau tidak tertarik terhadap objek sikap. Sikap (attitude) didefinisikan oleh Robbins (2006:93) sebagai pernyataan evaluatif, baik yang menyenangkan maupun tidak menyenangkan terhadap objek, individu, atau peristiwa. Hal ini mencerminkan bagaimana perasaan seseorang tentang sesuatu.

Kreitner dan Kinicki (2005:182) mendefinisikan sikap sebagai kecenderungan merespon sesuatu secara konsisten untuk mendukung atau tidak mendukung dengan memperhatikan objek tertentu.

Menurut Berkowitz (dalam Azwar, 2005:4) bahwa pengertian sikap dapat dimasukan ke dalam salah satu di antara tiga kerangka pemikiran, yaitu

a. Sikap adalah suatu bentuk evaluasi atau reaksi perasaan.

Sikap seseorang terhadap suatu objek adalah perasaan yang men-dukung atau favourable dan perasaan tidak mendukung atau unfavourable pada objek tersebut. Misalnya, menyetujui terjadinya reformasi di berbagai bidang kehidupan (favourable) dan tidak menyetujui terjadinya reformasi diberbagai bidang kehidupan (unfavourable)

b. Sikap merupakan kesiapan untuk bereaksi terhadap suatu objek dengan cara-cara tertentu. Kesiapan yang dimaksud adalah kecen-derungan potensial untuk bereaksi terhadap stimulus yang meng-hendaki suatu respon.

c. Sikap merupakan konsistensi dari komponen-komponen kognitif, afektif, dan konatif.

Berdasarkan beberapa pendapat tersebut, dapat disimpulkan bahwa sikap adalah arah dan intensitas perasaan yang didasarkan atas hasil organisasi keyakinan, penalaran, pemahaman dan penghayatan mengenai sesuatu yang relatif tetap serta memberi motivasi kepada individu tersebut untuk membuat respon secara positif atau negatif terhadap individu lain, objek atau situasi.

Ditinjau dari strukturnya, sikap terdiri atas tiga komponen, yaitu komponen kognitif, afektif, dan konatif.

\section{Komponen Kognitif}

Menurut Azwar (2005:25) bahwa suatu kepercayaan datang dari apa yang telah kita lihat dan diketahui, kepercayaan ini akan terus berkembang. Sears et al. (1994:138) menambahkan bahwa pada dasarnya kita memiliki banyak tentang pikiran dan keyakinan terhadap suatu. Walgito (2003: 111) mengatakan bahwa faktor kognisi menyangkut tentang bagaimana individu mempersepsi terhadap objek sikap.

\section{Komponen Afektif}

Komponen ini menyangkut tentang masalah emosi individu. Aspek ini berakar paling dalam terhadap pengaruh-pengaruh yang dapat merubah sikap individu. Sears et al. (1994:138) mengatakan bahwa komponen afektif terdiri dari seluruh perasaan atau emosi individu terhadap suatu objek atau peristiwa, terutama tentang penilaiannya. Azwar (2005:26) menyatakan bahwa pada umumnya perasaan individu 
terhadap suatu objek telah banyak ditentukan oleh suatu kepercayaan. Jadi, bila individu cenderung percaya pada suatu objek, ia akan bersikap positif terhadap objek tersebut. Walgito (2003 : 111) mengatakan bahwa komponen afektif merupakan komponen yang menentukan arah sikap baik positif maupun negatif.

\section{Komponen Konasi}

Komponen ini berisi suatu kecenderungan individu berperilaku terhadap suatu objek tertentu. Sears et al. (1994:138) merumuskan tentang komponen ini sebagai kesiapan. Pada dasarnya, komponen ini meliputi bentuk perilaku yang tidak hanya dapat dilihat secara langsung saja, tetapi juga meliputi bentuk-bentuk perilaku yang berupa pernyataan yang diucapkan individu.

\section{Sikap Berbahasa Indonesia}

Sikap bahasa (language attitude) adalah peristiwa kejiwaan dan merupakan bagian dari sikap pada umumnya. Sikap berbahasa merupakan reaksi penilaian terhadap bahasa tertentu. Sikap bahasa adalah posisi mental atau perasaan terhadap bahasa sendiri atau orang lain (Kridalaksana 2001:197).

Sikap bahasa itu dapat digolongkan dalam dua kelompok, yaitu sikap bahasa dan sikap nonbahasa. Sikap bahasa ditandai oleh tiga ciri, yaitu a. kesetiaan bahasa (language loyality), b. kebanggaan bahasa (language pride), dan c. kesadaran adanya norma bahasa (awareness of the norm). Kesetiaan bahasa menurut konsep tersebut adalah sikap yang terdorong suatu masyarakat untuk turut mempertahankan kemandirian, apabila perlu mencegah mamsuknya pengaruh asing. Kebanggan bahasa merupakan sikap yang mendorong seseorang atau kelompok menjadikan bahasanya sebagai lambang identitas pribadi atau kelompoknya dan sekaligus membedakannya dari orang atau kelompok lain. Sementara itu, kesadaran adanya norma bahasa mendorong penggunaan bahasa secara cermat. Kesadaran yang demikian merupakan faktor yang sangat menentukan perilaku tutur dalam wujud pemakaian bahasa (langauage use) Anderson (2002). Kesetiaan bahasa, kebanggaan bahasa, dan kesadaran bahasa akan adanya norma bahasa merupakan ciri-ciripositif terhadap suatu bahasa (Garvin dan Mayhiot dalam Suwito 1989:149).

Penerapan berbahasa dalam skripsi disebabkan oleh berbagai faktor, salah satunya adalah sikap berbahasa. Straks dan Paltridge (1996) mengatakan bahwa learning a language is closely related to the attitudes toward the languages. Bahwa mempelajari bahasa sangat dekat hubungannya dengan sikap berbahasa. Baker (dalam Starks dan Paltridge 1996) menyebutkan sebagai berikut.

"Attitude refers to a hypothetical 'construct used to explain the direction and persistence of human behaviour'. In other words, it can represent internal thoughts, feelings and tendencies in behaviour across a variety of contexts. Although an attitude is individual, it has origins in collective behaviour".

Meskipun sikap itu bersifat individual, namun memiliki asal dari perilaku kolektif (Baker dalam Starks dan Paltridge 2010). Baker (1988:112115) yang dikutip oleh Siregar (2010) juga mengatakan bahwa attitudes also play a vital role in language growth or decay, restoration or destruction. In other words, the status and importance of a language in society and within an 
individual can be adopted and learnt. Sikap juga memainkan peranan penting dalam tumbuh atau rusaknya bahasa, restorasi atau kehancurannya. Dengan kata lain, status dan pentingnya bahasa dalam masyarakat dan dalam diri seorang individu dapat diadopsi dan dipelajari.

\section{Penyusunan Skripsi}

Skripsi merupakan karya ilmiah sebagai hasil penuangan gagasan penulis. Sarana penuangan gagasan tersebut berupa kalimat yang saling berkaitan membentuk rentetan kalimat yang menjadi wacana. Wacana merupakan satuan bahasa terlengkap, realisasinya tampak pada bentuk karangan yang utuh, seperti novel, buku, dan artikel, atau pidato khotbah, dan sebagainya (Purwodarminto (1999:1122.

Wacana yang baik harus mempunyai topik atau pokok pembicaraan. Topik yaitu proposisi yang berwujud frasa atau kalimat yang menjadi inti pembicaraan (Alwi et al. 2003:435). Jadi, skripsi sebagai karangan yang utuh termasuk dalam lingkup wacana, di dalamnya terdapat makna yang serasi di antara kalimat-kalimat, sebagai sarana unsur pembentuk wacana. Keserasian makna itu berkaitan dengan makna kata yang dipakai. Menurut Arifin (2003:3) skripsi adalah karya tulis ilmiah yang mengemukakan pendapat penulis berdasarkan pendapat orang lain. Pendapat yang disajikan harus didukung oleh data dan fakta empiris-objektif, baik berdasarkan penelitian langsung maupun tidak langsung.

Ragam bahasa ilmiah menggunakan ragam bahasa baku. Alwi et al. (2003:12) mengemukakan bahwa ragam baku dijadikan tolok bandingan bagi pemakaian bahasa yang benar. Keraf (2000:48-49) berpendapat bahwa struktur gramatikal yang baik bukan merupakan tujuan dalam berkomunikasi, tetapi sekadar alat untuk menghasilkan sebuah pikiran atau maksud dengan sejelas-jelasnya. Ada unsur lain yang harus dipertimbangkan dalam pemakaian bahasa, yaitu segi penalaran atau logika. Jalan pikiran penulis turut menentukan baik-tidaknya bahasa seseorang, mudahtidaknya pikirannya dapat dipahami. Kalimat-kalimatnya harus bisa dipertanggungjawabkan dari segi akal sehat yang sesuai dengan penalaran karena bahasa tidak bisa lepas dari penalaran.

Dikatakan oleh Mustakim (1994:

68) bahwa sebuah kalimat dikatakan lengkap jika sekurang-kurangnya mengandung dua unsur, yaitu unsur subjek dan predikat. Keefektifan kalimat bisa terwujud apabila kalimat-kalimat yang dijalin memenuhi kaidah ketatabahasaan, sehingga kalimatnya gramatikal, sesuai dengan kaidahnya. Soedjito (1991:1) menyebutkan bahwa kalimat efektif adalah kalimat yang memenuhi kriteria, antara lain mengikuti kaidah gramatikal dan menggunakan kata (diksi) yang tepat. Sementara itu, Arifin dan Tasai (2000:90) dan Keraf (2001:36) mengemukakan bahwa sebuah kalimat efektif mempunyai ciri-ciri khas, yaitu kesepadanan struktur, keparalelan bentuk, ketegasan makna, kehematan kata, kepaduan gagasan (kohesi dan koherensi), kevariasian, dan kelogisan bahasa.

Kegramatikalan kalimat akan terwujud apabila kalimat yang dijalin disusun secara teratur sesuai dengan kaidahnya, mencakupi keteraturan susunannya, kohesi dan koherensi, kesepadanan struktur, keparalelan bentuk, kehematan kata, ketegasan makna, kevariasian, dan kelogisan bahasa. 


\section{Rumusan Masalah}

Berdasarkan masalah yang teridentifikasi rumusan masalah penelitian ini adalah sebagai berikut.

1. Apakah sikap berbahasa berpengaruh terhadap penerapan bahasa Indonesia dalam skripsi mahasiswa Fakultas Ilmu Budaya, Universitas Diponegoro, Semarang?

2. Bagaimanakah bentuk pengaruh sikap berbahasa Indonesia dalam penerapan berbahasa pada skripsi mahasiswa Fakultas Ilmu Budaya, Universitas Diponegoro, Semarang?

\section{Tujuan Penelitian}

Berdasarkan rumusan masalah tersebut, penelitian ini bertujuan untuk

1. mendeskripsi apakah sikap berbahasa berpengaruh terhadap penerapan bahasa Indonesia pada skripsi mahasiswa Fakultas Ilmu Budaya, Universitas Diponegoro, Semarang?

2. mendeskripsi bentuk pengaruh sikap berbahasa Indonesia terhadap penerapan berbahasa pada skripsi mahasiswa Fakultas Ilmu Budaya, Universitas Diponegoro, Semarang?

\section{Manfaat Penelitian}

Hasil penelitian ini diharapkan bermanfaat untuk kepentingan teoretis dan kepentingan praktis.

1. Manfaat teoretis penelitian ini diharapkan dapat memberikan sumbangan bagi proses pembelajaran bahasa Indonesia di perguruan tinggi yang berkaitan dengan temuan hasil penelitian..

2. Manfaat praktis dalam penelitian ini diharapkan dapat memberikan sumbangan kepada mahasiswa dan dosen mata kuliah Bahasa Indonesia dalam rangka menulis skripsi dengan berlandaskan temuan hasil ini.

\section{METODE PENELITIAN}

Penelitian ini dilakukan di Fakultas Ilmu Budaya, Universitas Diponegoro, Semarang dengan mengambil objek mahasiswa sebanyak 80 orang. Penelitian telah dilaksanakan selama empat bulan, sejak SeptemberDesember 2014 yang mencakupi perizinan, pengambilan data, analisis data, penyusunan laporan, dan pertanggungjawaban laporan.

\section{Sumber Data}

Sumber data yang digunakan untuk menelaah pengaruh sikap berbahasa adalah mahasiswa dari Program Studi Bahasa, Fakultas Ilmu Budaya, Universitas, Diponegoro Semarang. Peneliti beranggapan bahwa mahasiswa yang tidak memiliki sikap positif terhadap mata kuliah Bahasa Indonesia yang dipelajarinya tidak akan memperoleh hasil yang memuaskan. Metode pengungkapan sikap dalam bentuk self-report dengan menggunakan daftar pernyataan-pernyataan yang harus dijawab oleh individu yang disebut sebagai skala sikap. Metode rating yang dijumlahkan populer dengan nama penskalaan model Likert, yaitu merupakan metode penskalaan pernyataan sikap yang menggunakan ditribusi respons sebagai dasar penentuan skalanya.

Instrumen pengumpulan data sikap berbahasa dalam penelitian ini adalah kuesioner yang berisi pernyataan sikap bahasa Indonesia sebagai mata kuliah. Pernyataan sikap berbahasa tersebut disusun berdasarkan tiga aspek, yaitu aspek kognitif, afektif, dan konatif. Rancangan alat ukur sikap berbahasa dalam penelitian ini disajikan pada Tabel 1. Sementara itu, instrumen secara lengkap disajikan pada Lampiran 2. 


\section{Analisis Data}

Dalam penelitian ini, digunakan analisis deskriptif dengan menggunakan statistik deskriptif (skor terendah, skor tertinggi, skor rata-rata, dan standar deviasi) untuk menganalisis data sikap berbahasa. Data variabel sikap berbahasa dijaring dengan 18 butir pernyataan sebagaimana disajikan pada Lampiran 2. Dari 18 butir pernyataan tersebut, skor terendah yang mungkin diperoleh adalah 18, tertinggi 90 , sedangkan rata-ratanya idealnya adalah 54. Kriteria sikap berbahasa yang dikategorikan positif dan negatif diambil dari nilai rata-rata nilai idealnya. Artinya, mahasiswa dikategorikan bersikap positif jika memperoleh skor $\geq$ rata-rata ideal dan bersikap negatif jika skor yang diperoleh kurang dari rata-rata nilai ideal.

\section{Pemaparan Hasil Penelitian}

Pemaparan hasil penelitian ini menggunakan metode penyajian formal, baik dalam bentuk data kuantitatif (absolut, relatif) maupun data kualitatif (kalimat verbal). Penyajian formal untuk mendeskripsi data sikap berbahasa, sedangkan penyajian informal untuk mendeskripsi data pengaruh sikap berbahasa. Penyajian informal dilakukan karena bentuk paparannya berupa deskripsi dengan kata-kata biasa.

Hasil penelitian ini mencakupi survei pendahuluan, pengambilan data, pengisian kuesioner oleh mahasiswa, wawancara dengan mahasiswa, tabulasi data, analisis data, interpretasi data, dan penyusunan laporan penelitian. Kegiatan tersebut untuk mengetahui pengaruh sikap berbahasa terhadap penerapan bahasa Indonesia dalam penulisan skripsi mahasiswa Fakultas Ilmu Budaya, Universitas Diponegoro. Hasil penelitian tersebut dipaparkan sebagai berikut.

Tabel 1

Alat Ukur Variabel Sikap Berbahasa

\begin{tabular}{|l|c|c|c|c|}
\hline $\begin{array}{l}\text { Ciri } \\
\text { tur }\end{array}$ & $\begin{array}{c}\text { Kese } \\
\text { tiaan } \\
\text { baha } \\
\text { sa }\end{array}$ & $\begin{array}{c}\text { Kebang } \\
\text { gaan } \\
\text { bahasa }\end{array}$ & $\begin{array}{c}\text { Kesadaran } \\
\text { adanya } \\
\text { norma } \\
\text { bahasa }\end{array}$ & $\begin{array}{c}\text { Jum } \\
\text { lah }\end{array}$ \\
\hline Kognitif & 1,4 & 7,10 & 13,16 & 6 \\
\hline Afektif & 2,5 & 8,11 & 14,17 & 6 \\
\hline Konatif & 3,6 & 9,12 & 15,18 & 6 \\
\hline Jumlah & 6 & 6 & 6 & 18 \\
\hline
\end{tabular}

\section{Deskripsi dan Analisis Sikap Berbahasa \\ Untuk menganalisis sikap}

berbahasa, telah dilakukan pengambilan data dengan menyebarkan kuesioner kepada 80 orang mahasiswa Fakultas Ilmu Budaya, Universitas Diponegoro yang diambil secara acak mendadak (accidental random sampling).

Hasil perhitungan dengan menggunakan exsel 2007 diperoleh hasil bahwa dari 80 orang mahasiswa, diperoleh data bahwa nilai skor minimum sikap berbahasa adalah 81 poin, maksimum 89 poin, dan rata-rata 85,59 poin, dengan standar deviasi sebesar 1,82 poin. Sebaran skor yang menunjukkan sikap berbahasa mahasiswa Fakultas Ilmu Budaya, Universitas Diponegoro disajikan pada diilustrasikan pada Gambar 1.

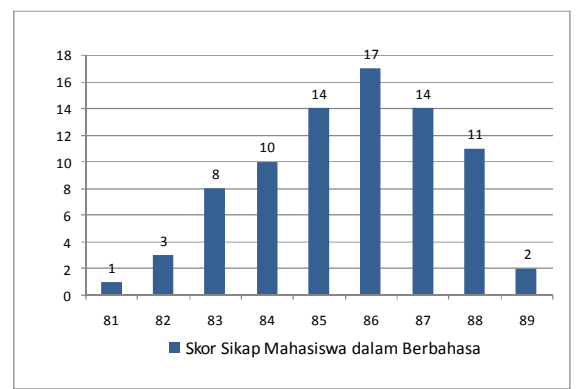

Penentuan kriteria sikap berbahasa, berdasarkan nilai teoretis skor 
minimum, maksimum, rata-rata, dan standar deviasi, diperoleh 5 kategori sikap berbahasa sebagaimana ditunjukkan pada Tabel 2.

\section{Tabel 2 Skor Sikap Berbahasa Mahasiswa Fakultas Ilmu Budaya, Undip}

\begin{tabular}{|l|l|c|c|}
\hline $\begin{array}{c}\text { Kriteria } \\
\text { Pemeroleh } \\
\text { an Skor }\end{array}$ & Kategori & $\begin{array}{l}\text { Jumlah } \\
\text { orang }\end{array}$ & $\%$ \\
\hline$\leq 36$ & $\begin{array}{l}\text { Sangat } \\
\text { tidak } \\
\text { setuju }\end{array}$ & 0 & 0 \\
\hline $\begin{array}{l}36 \leq \mathrm{X} \leq \\
48\end{array}$ & $\begin{array}{l}\text { Tidak } \\
\text { setuju }\end{array}$ & 0 & 0 \\
\hline $49 \leq \mathrm{X} \leq$ & $\begin{array}{l}\text { Cukup } \\
\text { Menyetu } \\
\text { jui }\end{array}$ & 0 & 0 \\
\hline $61 \leq \mathrm{X} \leq$ & $\begin{array}{l}\text { Menyetu } \\
\text { jui }\end{array}$ & 0 & 0 \\
71
\end{tabular}

Berdasarkan hasil perhitungan sebagaimana terlihat pada Tabel 2 dapat diketahui bahwa mahasiswa memiliki sikap positif dalam berbahasa. Semua mahasiswa yang menjadi sampel penelitian $(100 \%)$ sangat menyetujui tentang penggunaan bahasa Indonesia yang baik dan benar dalam menulis skripsi.

Deskripsi dan Analisis Penerapan Bahasa Indonesia dalam Skripsi Mahasiswa Fakultas Ilmu Budaya, Universitas Diponegoro

Berdasarkan hasil temuan penelitian terhadap delapan Skripsi Mahasiswa Fakultas Ilmu Budaya, Universitas Diponegoro ditemukan 1425 buah kalimat. Dari 1425 buah kalimat, ditemukan 1.002 buah kalimat gramatikal yang penerapannya sesuai dengan kaidah bahasa Indonesia yang baik dan benar dan 286 buah kalimat yang penerapannya tidak sesuai dengan kaidah bahasa Indonesia yang baik dan benar. Ketidaksesuain penerapan berbahasa tersebut disebabkan kalimat tidak gramatikalan. Ketidakgramatikalan kalimat tersebut disebabkan oleh kalimat tanpa subjek, tanpa predikat, dengan 2 subjek, 2 predikat, dan kalimat dengan 2 subjek dan 2 predikat, serta kalimat tanpa subjek dan tanpa predikat. Temuan hasil penelitian. atas penerapan bahasa Indonesia dalam skripsi mahasiswa Fakultas Ilmu Budaya, Universitas Diponegoro, menunjukkan bahwa ditemukan kalimat gramatikal sebanyak 1.002 buah, tidak gramatikal 286 buah, dan kesalahan dalam pemilihan kata/diksi dan kesalahan penerapan ejaan sejumlah 137 buah kalimat, dari jumlah 1.425 kalimat yang diteliti. Sementara itu, jika dirinci temuan kalimat yang tidak gramatikal tersebut sebagaimana ditunjukkan pada Tabel 3.

\section{Tabel 3 Temuan Kalimat yang Tidak} Gramatikal

\begin{tabular}{|c|l|c|}
\hline No. & Tidak Gramatikal & Jumlah \\
\hline 1. & Kalimat tanpa S & 96 \\
\hline 2. & Kalimat tanpa P & 52 \\
\hline 3. & Kalimat dengan 2 S & 32 \\
\hline 4. & Kalimat dengan 2 P & 20 \\
\hline 5. & $\begin{array}{l}\text { Kalimat dengan 2 S } \\
\text { dan 2 P }\end{array}$ & 30 \\
\hline 6. & $\begin{array}{l}\text { Kalimat tanpa S } \\
\text { dan tanpa P }\end{array}$ & 56 \\
\hline & Total & $\mathbf{2 8 6}$ \\
\hline
\end{tabular}

Berikut ini temuan hasil penelitian atas penerapan bahasa Indonesia dalam skripsi mahasiswa Fakultas Ilmu Budaya, Universitas Diponegoro. 


\section{Kalimat Tanpa Subjek}

Berdasarkan temuan hasil penelitian atas penerapan bahasa Indonesia dalam skripsi mahasiswa Fakultas Ilmu Budaya, Universitas Diponegoro ditemukan kalimat yang tidak efektif karena tidak bersubjek. Berikut ini contoh kalimat yang dimaksud.

a. Dikatakan sebagai pelaksanaan negatif karena napi tersebut menggunakan kata-kata yang kurang sopan atau tidak sepatutnya. (D.N. 2011: 45)

Perbaikan kalimat tersebut adalah sebagai berikut.

(1a $)$ Tuturan tersebut dikatakan sebagai pelaksanaan negatif karena napi tersebut menggunakan kata-kata yang kurang sopan atau tidak sepatutnya.

Subjek kalimat $\left(1 \mathrm{a}_{1}\right)$ adalah tuturan tersebut dan predikatnya adalah dikatakan sebagai pelaksanaan negatif karena napi tersebut menggunakan katakata yang kurang sopan atau tidak sepatutnya. Urutan fungsi-fungsi sintaksis kalimat tersebut adalah subjek dan predikat. Jadi, kalimat tersebut berpola S-P.

\section{Kalimat Tanpa Predikat}

Berikut ini temuan hasil penelitian kalimat tanpa predikat.

a. Masalah keterasingan manusia oleh Idayu Kristanti melalui tokoh Genta Melodi. (H.S. 2011: 45)

Untuk membetulkan kalimat (2a) dilakukan penambahan verba digambarkan agar berpredikat, sedangkan pada kalimat (2b) dilakukan penambahan kata dengan tujuan untuk mengisi fungsi predikat. Berikut ini pembetulan kalimat tersebut.

$\begin{array}{llr}\left(2 \mathrm{a}_{1}\right) & \text { Masalah keterasingan manusia } \\ \text { oleh Idayu } & \text { Kristanti } \\ & \text { digambarkan melalui tokoh } \\ & \text { Genta Melodi. }\end{array}$

Subjek kalimat $\left(2 \mathrm{a}_{1}\right)$ adalah masalah keterasingan manusia oleh Idayu Kristanti, predikatnya adalah digambarkan, dan keterangannya adalah melalui tokoh Genta Melodi. Urutan fungsi-fungsi sintaksis kalimat tersebut adalah subjek, predikat, dan keterangan. Jadi, pola urutan kalimat $\left(2 \mathrm{a}_{1}\right)$ adalah $\mathrm{S}$ P-K.

\section{Kalimat dengan 2 Subjek}

Berikut ini temuan kalimat dengan 2 subjek.

a. Hal ini beban kerja dilukiskan Idayu Kristanti sebagai berikut.... (H.S. 2011: 59)

Kalimat (a) merupakan kalimat dengan 2 subjek. Subjek 1 adalah hal ini dan subjek 2 adalah beban kerja. Berikut ini pembetulan kalimat tersebut

$\left(a_{1}\right)$ Hal ini merupakan lukisan beban kerja Idayu Kristanti yang diceritakan sebagai berikut....

Subjek kalimat $\left(\mathrm{a}_{1}\right)$ adalah hal ini, predikatnya adalah merupakan, dan objeknya adalah lukisan beban kerja Idayu Kristanti yang diceritakan sebagai berikut....Urutan fungsi-fungsi sintaksis kalimat tersebut adalah subjek, keterangan, predikat, dan objek. Jadi, pola urutan kalimat $\left(\mathrm{a}_{1}\right)$ adalah S-P-O.

\section{Kalimat dengan 2 Predikat}

Berdasarkan temuan hasil penelitian juga ditemukan kalimat dengan 2 predikat sebagaimana contoh kalimat berikut. 
a. Hal ini diperkuat dengan DP mengucapkan terimakasih kepada C.N. (S 2014: 42)

Pembetulan kalimat tersebut adalah sebagai berikut.

$\left(a_{1}\right)$ Hal ini diperkuat dengan ucapan terima kasih DP kepada CN.

\section{Kalimat dengan 2 Subjek dan 2 Predikat}

Penerapan kaidah bahasa pada kalimat berikut tidak benar subjek dan 2 predikat ditemukan karena bersubjek dan berpredikat ganda. Berikut ini contoh kalimat yang dimaksud.

a. Projo merupakan direktur bank yang terkena kasus korupsi, ia ditahan dan menjalani proses masa hukuman. (S.D. 2013: 33)

Pada kalimat (a), subjek 1 adalah Projo, subjek 2 adalah $i a$, predikat 1 , yaitu merupakan, dan predikat 2 adalah ditahan dan menjalani. Subjek 1 pada kalimat (b) adalah saat, subjek 2 adalah $D P$ dan predikat 1 adalah diajak dan predikat 2 adalah merendah diri. Pembetulan kalimat tersebut adalah sebagai berikut.

$\left(a_{1}\right)$ Projo merupakan direktur bank yang terkena kasus korupsi.

Subjek kalimat $\left(\mathrm{a}_{1}\right)$ adalah Projo, predikatnya adalah merupakan, dan pelengkapnya adalah direktur bank yang terkena kasus korupsi. Urutan fungsifungsi sintaksis kalimat tersebut adalah subjek, predikat, dan pelengkap. Jadi, pola urutan kalimat $\left(\mathrm{a}_{1}\right)$ adalah S-P-Pel.

\section{Kalimat tanpa Subjek dan tanpa Predikat}

Berikut ini contoh kalimat tanpa subjek dan tanpa predikat. a. Sedangkan mengenai data pribadi istri, suami memiliki hak penuh.

(H.S. 2011: 39) tersebut.

Berikut ini pembetulan kalimat

$\left(a_{1}\right)$ Suami memiliki hak penuh atas data pribadi istri.

Subjek kalimat $\left(\mathrm{a}_{1}\right)$ adalah suami predikatnya adalah memiliki, dan objeknya adalah memiliki hak penuh atas data pribadi istri. Urutan fungsi-fungsi sintaksis kalimat tersebut adalah subjek, predikat, dan objek. Jadi, pola urutan kalimat $\left(\mathrm{a}_{1}\right)$ adalah S-P-O.

\section{Kalimat Tidak logis}

Berikut ini temuan hasil penelitian kalimat yang tidak logis.

a. Kepolosan Wisuni membuat suasana menjadi bercanda saat terakhir penyamaran ini terbongkar. (S.D. 2013: 26)

Ketidaklogisan pada kalimat (a) tidak logis terjadi karena penggunaan frasa suasana menjadi bercanda. Kata yang tepat untuk menggantikannya adalah cair. Pembetulan kalimat tersebut adalah sebagai berikut.

$\left.\mathrm{a}_{1}\right)$ Kepolosan Wisuni membuat suasana menjadi cair pada saat terakhir penyamaran ini terbongkar.

\section{Kalimat yang Ambigu}

Hasil temuan kalimat yang ambigu di antaranya adalah sebagai berikut.

a. Latar peristiwa percakapan di atas adalah DP bertemu dengan $\mathrm{CN}$ yang sudah pernah kalah atau loss dalam berinvestasi. (S. 2014: 58) 
Keambiguan pada kalimat (a) adalah yang sudah pernah kalah atau loss dalam berinvestasi bisa DP, bisa juga CN. Berikut ini pembetulan kalimat tersebut.

$\left(a_{1}\right)$ Latar peristiwa percakapan di atas adalah DP bertemu dengan $\mathrm{CN}$.

Keambiguan pada kalimat (b) adalah ketiga unsur nama, yaitu Genta Melodi Kania tanpa dipisahkan tanda baca koma. Jadi, seperti nama satu orang, padahal dua nama, yaitu Genta Melodi dan Kania. Oleh karena itu, untuk menghilangkan keambiguan, kalimat tersebut dapat diperbaiki sebagai berikut.

\section{SIMPULAN DAN SARAN Simpulan}

Berdasarkan perhitungan dengan menggunakan exsel 2007 bahwa dari 80 orang mahasiswa diperoleh data nilai skor minimum sikap berbahasa adalah 81 poin, maksimum 89 poin, dan ratarata 85,59 poin, dengan standar deviasi sebesar 1,82 poin. Berdasarkan temuan hasil penelitian dan analisis deskriptif data statistik tentang pengaruh sikap berbahasa terhadap penerapan bahasa Indonesia dalam penulisan skripsi mahasiswa Fakultas Ilmu Budaya, Universitas Diponegoro disimpulkan bahwa semua mahsiswa (100\%) memiliki sikap berbahasa yang sangat baik. Mahasiswa menyetujui sikap berbahasa yang baik, namun sebatas pada sikap karena perilaku yang ditunjukkan mahasiswa dalam berbahasa belum sesuai dengan skripsi yang dibuatnya. Mahasiswa kurang mampu menulis suatu karya ilmiah, khususnya skripsi dengan tata tulis dan bahasa sesuai dengan kaidah berbahasa yang benar. Mahasiswa menulis sesuai dengan yang dipikirkan tanpa memperhatikan kaidah penulisan dengan bahasa Indonesia yang baik dan benar. Sikapnya yang sangat menyetujui cara berbahasa yang benar ternyata tidak diikuti dengan perilaku menulis dengan bahasa yang benar pula.

Hal ini bisa dibuktikan berdasarkan hasil analisis atas skripsi mereka yang masih ditemukan kesalahan dalam berbahasa. Kesalahan mencakupi kesepadanan struktur, kesejajaran bentuk, ketepatan gagasan, kehematan kata, dan kelogisan dalam skripsi mahasiswa Fakultas Ilmu Budaya, Universitas Diponegoro ditemukan 1.425 buah kalimat yang gramatikal, 425 buah kalimat yang tidak gramatikal, serta 137 buah kalimat dengan penggunaan diksi dan ejaan tidak tepat. Ketepatan pilihan kata dan ketepatan penggunaan ejaan di dalam skripsi mahasiswa Fakultas, Universitas Diponegoro ditemukan sebanyak 1.288 buah kalimat dan 137 buah kalimat dengan makna dan ejaan yang tidak tepat. Ketidakgramatikalan kalimat dan ketidaktepatan pilihan kata serta ketidaktepatan penggunaan ejaan pada skripsi tersebut merupakan pengaruh sikap berbahasa mahasiswa.

\section{Saran}

Berdasarkan hasil analisis atas temuan penelitian, peneliti memberikan saran sebagai berikut. Penguasaan berbahasa Indonesia dengan baik dan benar diperlukan bagi mahasiswa dalam menulis skripsi agar menghasilkan bahasa yang berkualitas sebagai cerminan bahasa yang dipakai oleh para kaum terpelajar. Penerapan bahasa dalam skripsi sesuai dengan kaidahnya diperlukan oleh para mahasiswa agar apa yang dikomunikasikan tepat maknanya, sehingga mudah dipahami oleh pembaca. 


\section{DAFTAR PUSTAKA}

Ajzen, I. 2005. Attitude, Personality, and Behavior. New York : McGraw Hill.

Alwi, H., S. Dardjowidjojo, H. Lopaliwa, dan A.M. Moeliono. 2003. Tata Bahasa Baku Bahasa Indonesia. Edisi Ketiga. Jakarta: Balai Pustaka.

Anderson, M., H.C. Schools, and M. Keel. 2002. "Using Reasoning and Writing to Teach Writing Skills to Students with Learning Disabilities and Behavioral Disorders". Journal of Direct Instruction, 2 (1: 49-55). www.adihome.org/articles/ JDI_02_01_06. pdf. (23 Agustus 2011).

Arifin, E. Zaenal dan S. Amran Tasai . 2000. Cermat Berbahasa Indonesia untuk Perguruan Tinggi. Jakarta : Akademika Presindo.

Azwar, S. 2005. Sikap Manusia. Yogyakarta: Pustaka Belajar.

Baron, R. A. dan D. Byrne. 2004. Psikologi Sosial Jilid 1. (edisi 10). Jakarta : Erlangga.

Calhoun, J.F. and J.R. Acocella. 1995. Psychology of Adjustment and Human Relationship. New York: McGraw-Hill, Inc.

Fishbein, M., and I. Ajzen. 1975. Belief, Attitude, Intention, and Behavior: An Introduction to Theory and Research. Reading, MA: AddisonWesley.

Kridalaksana, Harimurti. 2001. Kamus Linguistik Jakarta: Gramedia.
Kreitner, R dan Kinicki, A. 2005. Perilaku Organisasi. Jakarta: Salemba

Moeliono, A.M. 1991. Santun Bahasa. Jakarta: Gramedia Pustaka Utama.

Notoatmodjo, S. 2005. Metodologi Penelitian Kesehatan. Jakarta: Rineka Cipta.

Robbins, S.P. 2006. Perilaku Organasasi. Jakarta : PT INDEKS

Sears, D.O., J.L. Freedman, and L.A. Peplau. 1994. Psikologi Social. Jakarta: Erlangga.

Siregar, F.L. 2010. "The Language Attitudes of Students of English Literature and D3 English at Maranatha Christian University toward American English, British English and Englishes in Southeast Asia, and their various contexts of use in Indonesia". Philippine ESL Journal, Vol. 4, hlm. 72. www.philippine-esljournal.com/V4_A4.pdf.(21 Agustus 2011).

Starks D., and B. Paltridge. 1996. "A Note on Using Sociolinguistic Methods to Study Nonnative Attitudes Toward English". World Englishes, $\quad 15(2: 217-224)$. http://onlinelibrary.wiley. com/doi/10.1111/j.1467971X.1996.tb00107.x/ abstract. (21 Agustus 2011).

Walgito, B. 2003. Psikologi Sosial (Suatu Pengantar), Edisi Revisi, Jogjakarta: Andi Offset. 
Widjono Hs. 2005. Bahasa Indonesia: Mata Kuliah Pengembangan
Kepribadian di Perguruan Tinggi. Jakarta: Grasindo. 